\title{
Effects of antioxidant enzymes and bioaccumulation in eels (Anguilla japonica) by acute exposure of waterborne cadmium
}

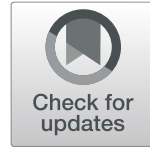

\author{
Tae-Young Ahn ${ }^{1}$, Hee-Ju Park², Jun-Hwan $\mathrm{Kim}^{3}$ and Ju-Chan Kang ${ }^{2^{*}}$ (D)
}

\begin{abstract}
This study was conducted to evaluate the acute effects of waterborne cadmium exposure on bioaccumulation and antioxidant enzymes in eels (Anguilla japonica) and to determine the median lethal concentration ( $\left.\mathrm{LC}_{50}\right)$. Fish were exposed to different cadmium concentrations $\left(0,0.15,0.30,0.61,1.83,3.08,3.67,4.29\right.$, and $\left.5.51 \mathrm{mg} \mathrm{L}^{-1}\right)$ for $96 \mathrm{~h}$. The $\mathrm{LC}_{50}$ of $A$. japonica to cadmium was $3.61 \mathrm{mg} \mathrm{L}^{-1}$. Cadmium accumulation generally increased in tissues with increasing waterborne cadmium concentrations. At $\geq 1.83 \mathrm{mg} \mathrm{L}^{-1}$ exposure, all tissues accumulated significant cadmium concentrations compared with the control group, in the order of kidney $>$ liver $>$ gill $>$ spleen $>$ muscle. Measurements of variation in actual cadmium concentrations showed that a reduction of the metal in experimental water was related to cadmium accumulation in tissues. As activity alteration of antioxidant enzymes for reactive oxygen species, superoxide dismutase and catalase activities increased at $\geq 0.61 \mathrm{mg} \mathrm{L}^{-1}$ significantly, glutathione peroxidase and glutathione S-transferase activities were not significantly changed. The results of this study suggest that acute exposure to waterborne cadmium is potentially fatal to A. japonica due to the metal's major accumulation in various tissues and the effect of antioxidant enzyme activity.
\end{abstract}

Keywords: Cadmium, Anguilla japonica, Acute toxicity, LC 50 , Bioaccumulation, Antioxidant enzyme

\section{Introduction}

Metals naturally exist in aquatic ecosystems, but side effects from industrialization have resulted in excessive concentrations. Exposure to high metal levels may negatively affect fish and other aquatic organisms, hampering physiological functions, growth rate, and reproduction, or even increasing mortality (Reddy and Reddy 2013; Öz 2018; Öz et al. 2018). Cadmium is a particularly widespread and toxic example that is documented to accumulate in exposed organisms; it is used primarily in alloys, pigments, electroplating, and batteries (Bryan 1976; Farag et al. 1995; Adriano 2001; Javed 2003).

In fish, Cd disrupts Ca metabolism through competition for transport sites on the basolateral calcium pumps

\footnotetext{
* Correspondence: jckang@pknu.ac.kr

${ }^{2}$ Department of Aquatic Life Medicine, Pukyong National University, Busan 48513, South Korea

Full list of author information is available at the end of the article
}

of gills (Verbost et al. 1987, 1988, 1989; Pinot et al. 2000). Cd redox activity affects antioxidants, thus reducing protection against oxidative stress, increasing lipid peroxidation, and decreasing DNA synthesis (Okorie et al. 2014). In addition, $\mathrm{Cd}$ lowers plasma $\mathrm{Na}, \mathrm{Cl}$, and $\mathrm{K}$, leading to hyperglycemia and hypermagnesemia (Larsson et al. 1981; Haux and Larsson 1984; Sjöbeck et al. 1984). Even at low concentrations, Cd deforms tissues and vertebrae, causing respiration abnormalities and death in fish (De Smet and Blust 2001). Cd and other toxic heavy metals can also accumulate through direct absorption or biomagnification; the resultant inhibition of major organ function (i.e., liver, kidney, and gills) is strongly linked to toxicity. Thus, the degree of accumulation in each organ is used frequently as a biomonitor for metal contamination (Handy 1992).

In fish exposed to $\mathrm{Cd}$, reactive oxygen species (ROS), such as hydrogen peroxide $\left(\mathrm{H}_{2} \mathrm{O}_{2}\right)$, hydroxyl, and oxygen

(c) The Author(s). 2020 Open Access This article is licensed under a Creative Commons Attribution 4.0 International License, which permits use, sharing, adaptation, distribution and reproduction in any medium or format, as long as you give appropriate credit to the original author(s) and the source, provide a link to the Creative Commons licence, and indicate if changes were made. The images or other third party material in this article are included in the article's Creative Commons licence, unless indicated otherwise in a credit line to the material. If material is not included in the article's Creative Commons licence and your intended use is not permitted by statutory regulation or exceeds the permitted use, you will need to obtain permission directly from the copyright holder. To view a copy of this licence, visit http://creativecommons.org/licenses/by/4.0/. 
radical, occur and induce oxidative stress. As a result, the biological system induces antioxidant enzymes, e.g., superoxide dismutase (SOD), catalase (CAT), glutathione peroxidase (GPx), glutathione S-transferase (GST), to mitigate the attack of ROS. These enzymes are used as stress biomarkers in fish by exposure or contamination of heavy metals and generation of ROS. SOD is catalyzing the transformation of superoxide anion radicals to $\mathrm{H}_{2} \mathrm{O}_{2}$ and oxygen $\left(\mathrm{O}_{2}\right)$. Catalase (CAT) decomposes toxic $\mathrm{H}_{2} \mathrm{O}_{2}$ to $\mathrm{O}_{2}$ and $\mathrm{H}_{2} \mathrm{O}$. Glutathione peroxidase (GPx) decomposes $\mathrm{H}_{2} \mathrm{O}_{2}$ or organic hydroperoxide to $\mathrm{H}_{2} \mathrm{O}$ or corresponding alcohols using reduced glutathione (GSH) into oxidized glutathione (GSSG). Glutathione S-transferase (GST) detoxifies the reactive intermediates and oxygen radicals by catalyzing the conjugation of GSH to various electrophilic metabolites, thereby enhancing water solubility and assisting excretion (Livingstone 2003).

Two standard tests of metal toxicity are acute or chronic exposure. In many organisms including fish, acute toxicity is defined as $\mathrm{LC}_{50}$ (median lethal concentration), a concentration that kills approximately $50 \%$ of a test group after exposure to increasingly higher toxicant levels for a specified, relatively short time frame (Schreck and Moyle 1990; Mason 1991). Acute toxicity data are supplemented with chronic toxicity tests for the same compound, exposing subject organisms to the same low concentration over a longer period. Such information is useful as a reference when performing environmental surveys of contaminated areas and determining the effects of toxicant efflux after industrial accidents.

Eels are commonly consumed in Asia and are mostly produced through aquaculture. Farmed eels are fed paste that contains a high ratio of fish meal. Thus, $\mathrm{Cd}$ accumulation can occur if the metal's concentration in fish meal is high. Eels suffer particularly high mortality under $\mathrm{Cd}$ exposure, because their benthic lifestyle increases contact with heavy metals that sink to the floor. These factors indicate that we require data on Cd effects in eels to ensure food safety and assess environmental contamination. However, despite the progress made on understanding the outcome of $\mathrm{Cd}$ exposure in several fish species (Handy 1993; Yilmaz et al. 2004; Aldoghachi et al. 2016), little research has been conducted in eels, especially Anguilla japonica. Furthermore, many bioaccumulation studies focus on chronic exposure, despite the possibility of industrial accidents causing acute $\mathrm{Cd}$ exposure and accumulation. If $\mathrm{Cd}$ in eels is highly accumulated after acute exposure, it can affect the health of humans as food through a catch. Thus, the purpose of this study is to assess risk as food, identify the effect on fish health, and utilize baseline data for chronic toxicity test by investigating accumulation in major tissues (liver, kidney, spleen, gills, and muscle) and change of antioxidant enzymes (SOD, CAT, GPx, and GST) in the liver with the determination of $\mathrm{LC}_{50}$ for $\mathrm{Cd}$ in adult $A$. japonica.

\section{Materials and methods}

Experimental fish and design

Anguilla japonica specimens were collected from the eel aquafarm of Paju city, Gyeonggi province, South Korea. Fish were acclimated to a polyvinyl (PVC) tank for 2 weeks prior to experiment and food-deprived. Also, we identified no infection of parasites in some fish before acclimation and toxicity test to prevent mortality by parasites and used visually healthy fish for the experiment.

Acute $\mathrm{Cd}$ toxicity test was conducted under laboratory conditions. Acclimated fish $(n=90$; average weight $186.6 \pm 11.9 \mathrm{~g})$ were selected, divided into nine groups (10 per group), and placed into plastic aquaria $(555 \times$ $395 \times 310 \mathrm{~mm}$ ) filled with underground water. Table 1 summarizes the water quality parameters measured for the bioassay. Water temperature was maintained with a heater at $29 \pm 1{ }^{\circ} \mathrm{C}$. To make conditions similar to aquafarm, the laboratory was kept in 24-h darkness except when checking fish mortality. During the exposure period, water was not renewed and fish were not fed. Analytical-grade $\mathrm{CdCl}_{2}$ (Aldrich, Inc., USA) was dissolved in triple distilled water to prepare stock $\mathrm{Cd}$ solution used for exposure experiments (see the "Determination of $\mathrm{LC}_{50}$ and assay of actual Cd levels in experimental water" section).

\section{Determination of $\mathrm{LC}_{50}$ and assay of actual Cd levels in experimental water}

Experimental fish were exposed to waterborne $\mathrm{CdCl}_{2}$ treatments of $0.25,0.5,1,3,5,6,7$, and $9 \mathrm{mg} \mathrm{L}^{-1}, 0.15$, $0.30,0.61,1.83,3.08,3.67,4.29$, and $5.51 \mathrm{mg} \mathrm{L}^{-1}$ as only

Table 1 Quality parameters of water used during acclimation and experimentation

\begin{tabular}{ll}
\hline Parameters & Value \\
\hline $\mathrm{pH}$ & $7.96 \pm 0.10$ \\
Salinity (\%o) & $\leq 0.1$ \\
Dissolved oxygen $\left(\mathrm{mg} \mathrm{L}^{-1}\right)$ & $7.75 \pm 0.05$ \\
Chemical oxygen demand $\left(\mathrm{mg} \mathrm{L}^{-1}\right)$ & $<0.01$ \\
$\mathrm{NH}_{3}-\mathrm{N}\left(\mathrm{mg} \mathrm{L}^{-1}\right)$ & $0.015 \pm 0.005$ \\
$\mathrm{NO}_{2}-\mathrm{N}\left(\mathrm{mg} \mathrm{L}^{-1}\right)$ & $0.003 \pm 0.001$ \\
$\mathrm{NO}_{3}-\mathrm{N}\left(\mathrm{mg} \mathrm{L}^{-1}\right)$ & $4.3 \pm 0.1$ \\
$\mathrm{SO}_{4}{ }^{2-}\left(\mathrm{mg} \mathrm{L}^{-1}\right)$ & $8.0 \pm 0.5$ \\
$\mathrm{PO}_{4}{ }^{3-}\left(\mathrm{mg} \mathrm{L}^{-1}\right)$ & $0.25 \pm 0.05$ \\
$\mathrm{SS}^{\left(\mathrm{mg} \mathrm{L}^{-1}\right)}$ & $28 \pm 2$ \\
$\mathrm{Total}^{2}$ hardness $\left(\mathrm{CaCO}_{3} \mathrm{mg} \mathrm{L}^{-1}\right)$ & $150 \pm 10$ \\
$\mathrm{Cd}^{2+}\left(\mathrm{mg} \mathrm{L}^{-1}\right)$ & $\leq 0.0001$ \\
\hline
\end{tabular}


Cd concentrations, for $96 \mathrm{~h}$. A water-only control was also used. $\mathrm{Cd}$ exposure concentrations were established after pre-experiment by referring to $\mathrm{Cd}$ chronic accumulation concentration $\left(0.1 \mathrm{mg} \mathrm{L}^{-1}\right)$ in eels, Anguilla japonica, through previous study (Yang and Chen 1996). Dead fish were counted every $12 \mathrm{~h}$ and removed immediately from the aquaria. Experimental water was collected to measure actual $\mathrm{Cd}$ concentrations at 12 and $96 \mathrm{~h}$ after adding the stock $\mathrm{Cd}$ solution. Water samples were diluted with $2 \%$ nitric acid before analysis using ICP-MS (inductively coupled plasma mass spectrometry; NexION 300X, Perkin-Elmer Inc., USA). The change rate and decrement of actual $\mathrm{Cd}$ were calculated as follows:

(1) Change rate $(\%)=100 \times(1-\mathrm{Cd}$ concentration at $96 \mathrm{~h} \div \mathrm{Cd}$ concentration at $12 \mathrm{~h}$ )

(2) Decrement $\left(\mathrm{mg} \mathrm{L}^{-1}\right)=\mathrm{Cd}$ concentration at $12 \mathrm{~h}-$ $\mathrm{Cd}$ concentration at $96 \mathrm{~h}$

\section{Tissue analysis to confirm $\mathrm{Cd}$ bioaccumulation}

After a 96-h Cd exposure, gills, liver, kidney, spleen, and muscle samples of live fish were collected and kept at $80^{\circ} \mathrm{C}$ until analysis. Tissues were freeze-dried and digested with nitric acid (Suprapur grade, Merck, Germany) and hydrogen peroxide (bioassay grade, Merck, Germany) in a microwave (START D, Milestone, Italy). The resultant solutions were diluted with triple distilled water and subjected to ICP-MS (NexION, Perkin-Elmer Inc., USA).

\section{Assay of antioxidant enzymes activity}

The Collected liver was homogenized with $0.1 \mathrm{M}$ phosphate-buffered saline (PBS) using tissue lyzer (TissueLyser II, QIAGEN, Germany). The homogenate was centrifuged at $10,000 \mathrm{~g}$ for $30 \mathrm{~min}$ under $4{ }^{\circ} \mathrm{C}$. The supernatants were obtained and stored at $-80^{\circ} \mathrm{C}$ until analysis. SOD activity was analyzed using the SOD assay kit (Dojindo Co., Japan) measuring 50\% inhibition rate for the reduction reaction of 2-(4-lodophenyl)-3-(4-nitrophenyl)-5-(2,4-disulfophenyl)-2 $\mathrm{H}$-tetrazolium monosodium salt (WST-1) and was expressed as $\mathrm{U} \mathrm{mg}$ protein $^{-1}$. CAT activity was analyzed using the CAT assay kit (Sigma-Aldrich Inc., USA) measuring the absorbance of the chromogen versus the amount of residual $\mathrm{H}_{2} \mathrm{O}_{2}$ after reaction with samples and was expressed as $\mathrm{U}$ mg protein ${ }^{-1}$. GPx activity was analyzed using the GPx cellular activity assay kit (Sigma-Aldrich Inc., USA) measuring the change in absorbance at 340 $\mathrm{nm}$ by the reduction reaction of tert-butyl hydroperoxide and was expressed as $U \mathrm{mg}$ protein $^{-1}$. GST activity was analyzed using the GST assay kit (Sigma-Aldrich Inc., USA) measuring the change in absorbance at $340 \mathrm{~nm}$ by reaction of sample and substrate solution including 1chloro-2,4-dinitrobenzene (CDNB) and was expressed as $\mu \mathrm{mol} \mathrm{min}^{-1} \mathrm{mg}$ protein ${ }^{-1}$. Total protein concentrations in the liver were determined using the method of Bradford (1976), with bovine serum albumin as a standard.

\section{Statistical analysis}

Finney's probit analysis was used to determine the $\mathrm{LC}_{50}$ of $\mathrm{Cd}$ in eels, along with confidence limits. Betweengroup differences in $\mathrm{Cd}$ bioaccumulation and activities of antioxidant enzymes were analyzed using two tests as a one-way ANOVA depending on Levene's test for equal variance. Duncan's multiple range and Games-Howell tests were used at $P>0.05$ and $P<0.05$ in equality of variances, respectively. Significance of post hoc test was set at $P<0.05$. All statistics were performed in SPSS version 20 (IBM co., USA).

(1) Duncan's multiple range test: kidney, SOD, CAT, GPx, and GST

(2) Games-Howell test: liver, spleen, gill, muscle

\section{Results}

\section{Median lethal concentrations of $\mathrm{Cd}$ in $\mathrm{A}$. japonica}

Mortality was first measured at a Cd concentration of $\geq$ $3.08 \mathrm{mg} \mathrm{L}^{-1}$, and the mortality rate reached $100 \%$ at 5.51 $\mathrm{mg} \mathrm{L}^{-1}$. The number of dead fish increased with increasing $\mathrm{Cd}$ concentration. Based on mortality data, $\mathrm{LC}_{50}$ of $\mathrm{Cd}$ in A. japonica after 24, 48, 72, and $96 \mathrm{~h}$ was 5.10, 4.04, 3.67, and $3.61 \mathrm{mg} \mathrm{L}^{-1}$, respectively (Table 2).

\section{Variation in actual Cd levels of experimental water}

Variation in the actual $\mathrm{Cd}$ concentration of experimental water was measured to investigate correlations between $\mathrm{Cd}$ accumulation in $A$. japonica and changes to $\mathrm{Cd}$ levels during the acute toxicity test. We found that actual $\mathrm{Cd}$ concentrations generally decreased after the 96$h$ exposure (Table 3). Based on measurements from 12-h post-exposure, the lowest and highest rate change in concentration were $5.1 \%$ (at exposure to $5.51 \mathrm{mg} \mathrm{L}^{-1} \mathrm{Cd}$ ) and $16.8 \%$ (at $1.83 \mathrm{mg} \mathrm{L}^{-1}$ ), respectively. In contrast, the lowest and highest absolute decrement of actual $\mathrm{Cd}$ concentration (again measured 12-h post-exposure) were $0.015 \mathrm{mg} \mathrm{L}^{-1}$ (at $0.15 \mathrm{mg} \mathrm{L}^{-1}$ ) and $0.664 \mathrm{mg} \mathrm{L}^{-1}$ (at 3.67 $\left.\mathrm{mg} \mathrm{L}^{-1}\right)$, respectively.

Table 2 Estimated median lethal concentrations $\left(L C_{50}\right)$ and confidence limits

\begin{tabular}{llll}
\hline $\begin{array}{l}\text { Period } \\
(\mathrm{h})\end{array}$ & $\begin{array}{l}\text { Concentration } \\
\left(\mathrm{Cd} \mathrm{mg} \mathrm{L}^{-1}\right)\end{array}$ & \multicolumn{2}{c}{$95 \%$ confidence limits } \\
\cline { 3 - 4 } & 5.10 & Lower & Upper \\
\hline 24 & 4.04 & 4.37 & 6.84 \\
48 & 3.67 & 3.55 & 4.66 \\
72 & 3.61 & 3.25 & 4.10 \\
96 & & 3.19 & 3.99 \\
\hline
\end{tabular}


Table 3 The change rate and decrement of actual $\mathrm{Cd}$ concentrations in experimental water at two time points (12and 96-h post-exposure) under different $\mathrm{Cd}$ concentrations

\begin{tabular}{|c|c|c|c|c|}
\hline \multirow{2}{*}{$\begin{array}{l}\text { Exposure } \\
\text { conc. (Cd } \\
\mathrm{mg} \mathrm{L}^{-1} \text { ) } \\
\end{array}$} & \multicolumn{2}{|c|}{ Actual Cd conc. (Cd mg L $\left.{ }^{-1}\right)$} & \multirow{2}{*}{$\begin{array}{l}\text { Change } \\
\text { rate (\%) }\end{array}$} & \multirow{2}{*}{$\begin{array}{l}\text { Decrement } \\
(\mathrm{Cd} \text { mg } \\
\left.\mathrm{L}^{-1}\right)\end{array}$} \\
\hline & $12 \mathrm{~h}$ & $96 \mathrm{~h}$ & & \\
\hline 0.15 & 0.156 & 0.141 & 9.6 & 0.015 \\
\hline 0.30 & 0.331 & 0.310 & 6.3 & 0.021 \\
\hline 0.61 & 0.662 & 0.624 & 5.7 & 0.039 \\
\hline 1.83 & 2.148 & 1.786 & 16.8 & 0.362 \\
\hline 3.08 & 3.064 & 2.763 & 9.8 & 0.302 \\
\hline 3.67 & 4.068 & 3.404 & 16.3 & 0.664 \\
\hline 4.29 & 4.624 & 4.177 & 9.6 & 0.448 \\
\hline 5.51 & 5.715 & 5.421 & 5.1 & 0.294 \\
\hline
\end{tabular}

\section{Bioaccumulation}

$\mathrm{Cd}$ exposure caused a net increase of $\mathrm{Cd}$ content in all tested A. japonica tissues compared with the control (Fig. 1). The order of $\mathrm{Cd}$ accumulation in tissues (including control) was as follows: kidney $>$ liver $>$ gills $>$ spleen $>$ muscle, with the highest and lowest concentrations being $122.190 \mathrm{mg} \mathrm{kg}^{-1}$ in the kidney (at $3.67 \mathrm{mg}$ $\mathrm{L}^{-1}$ ) and $0.049 \mathrm{mg} \mathrm{kg}^{-1}$ in the muscle (at $0.15 \mathrm{mg} \mathrm{L}^{-1}$ ) of exposed groups, respectively. As expected, accumulation rose with increasing exposure concentration. However, significant differences as compared with control in $\mathrm{Cd}$ accumulation across all tissues were observable at $\geq$ $1.83 \mathrm{mg} \mathrm{L}^{-1} \mathrm{Cd}$ exposure. Individually, significant differences were apparent at $\geq 0.15 \mathrm{mg} \mathrm{L}^{-1}$ in the gill and muscle, $\geq 0.30 \mathrm{mg} \mathrm{L}^{-1}$ in the liver, $\geq 0.61 \mathrm{mg} \mathrm{L}^{-1}$ in the kidney, and $\geq 1.83 \mathrm{mg} \mathrm{L}^{-1}$ in the spleen.

\section{Antioxidant enzymes activity}

After acute exposure to $\mathrm{Cd}$ during $96 \mathrm{~h}$, activities of antioxidant enzymes (SOD, CAT, GPx, and GST) in eel's liver were determined (Fig. 2). Activities of SOD and CAT increased as compared with control by increasing exposure concentration. Significant increase from control (as 1898 $\mathrm{U} \mathrm{mg} \mathrm{protein}^{-1}$ ) in SOD activity was observable at $\geq 1.83$ $\mathrm{mg} \mathrm{L}^{-1}$ (as $2811 \mathrm{Umg}$ protein ${ }^{-1}$ ) with the highest activity being $3195 \mathrm{Umg}_{\mathrm{mg}}$ protein ${ }^{-1}$ at $3.08 \mathrm{mg} \mathrm{L}^{-1} \mathrm{Cd}$ exposure. Significant increase from control (as $1021 \mathrm{U} \mathrm{mg} \mathrm{protein}^{-1}$ ) in CAT activity was observable at $\geq 0.61 \mathrm{mg} \mathrm{L}^{-1}$ with the highest activity being $1704 \mathrm{U} \mathrm{mg}$ protein ${ }^{-1}$ at $3.67 \mathrm{mg} \mathrm{L}^{-1}$ Cd exposure. GPx activity from control (as 0.1024 U mg protein $^{-1}$ ) decreased at 3.08 and $3.67 \mathrm{mg} \mathrm{L}^{-1} \mathrm{Cd}_{\text {exposure }}$ as 0.0644 and $0.0664 \mathrm{U} \mathrm{mg}$ protein $^{-1}$, respectively, but it is not significant. GST activity from control (as $0.2551 \mu \mathrm{mol}$ $\min ^{-1} \mathrm{mg}$ protein ${ }^{-1}$ ) was not changed at all groups.

\section{Discussion}

Like the findings of a general aquatic toxicity study (Rand et al. 1995), this study demonstrated that $A$. japonica mortality increased with increasing $\mathrm{Cd}$ concentration and exposure period. Although previous studies had attempted to examine acute $\mathrm{Cd}$ toxicity in freshwater fish (e.g., tilapia, common carp, rasbora) (Rehwoldt et al. 1972; Shuhaimi-Othman et al. 2015), these were generally not enough for the overall assessment of environmental pollution. Nonetheless, we compared our results with several previous studies to evaluate $\mathrm{Cd}$ acute toxicity (Table 4$)$. In contrast with $3.61 \mathrm{mg} \mathrm{L}^{-1}$ (after 96-h Cd exposure) in the $\mathrm{LC}_{50}$ of this study, the $\mathrm{LC}_{50}$ in tilapia sac fry (Oreochromis niloticus) and juvenile (Oreochromis sp.) were $1.6 \mathrm{mg} \mathrm{L}^{-1}$ (after 24h Cd exposure) and $0.7 \mathrm{mg} \mathrm{L}^{-1}$ (after 96-h Cd exposure), respectively (Andaya and Gotopeng 1982; Aldoghachi et al. 2016). Moreover, the 96-h $\mathrm{LC}_{50}$ of $\mathrm{Cd}$ in adult guppies (Poecilia reticulata) was $30.4 \mathrm{mg} \mathrm{L}^{-1}$ (Yilmaz et al. 2004), while it was $7.42 \mathrm{mg} \mathrm{L}^{-1}$ in juvenile piauçu (Luciobrama microcephalus) (Gomes et al. 2009). These data indicate that between-species differences in life history, genetic composition, and individual conditions have a greater impact on fish tolerance (or sensitivity) to Cd toxicity than size and age (Rand et al. 1995). Ideally, within-species comparisons would better indicate whether our results are typical of $A$. japonica. However, although some studies examining acute $\mathrm{Cd}$ toxicity do exist for this species, differences in experimental water conditions (e.g., hardness, pH, temperature) complicate the interpretation of any cross-study variation (Shuhaimi-Othman et al. 2015). Regardless, this study provides important basic data for any future study investigating chronic $\mathrm{Cd}$ toxicity in $A$. japonica and allows for further comparative analyses of $\mathrm{Cd}$ tolerance among fish.

$\mathrm{Cd}$ accumulation in tissues may differ according to metal's form. Inorganic Cd tends to be accumulated in the liver, while $\mathrm{Cd}$-thiols are readily accumulated in the kidney, considered the organ most sensitive to Cd toxicity (Hammond and Foulkes 1986; Woo et al. 1993; Okorie et al. 2014). Here, we demonstrated that Cd accumulation was higher in the kidney and liver than other tissues, with significant differences from control at $\geq 0.61 \mathrm{mg} \mathrm{L}^{-1} \mathrm{Cd}$ exposure. Furthermore, both organs had greater $\mathrm{Cd}$ concentrations even in the control condition. This result corroborates previous study; in A. japonica exposed to 0.05 $\mathrm{mg} \mathrm{L}^{-1}$ of $\mathrm{Cd}$, the primary tissues that accumulated $\mathrm{Cd}$ were the kidney and liver (Yang and Chen 1996). The previous study suggested that the two tissues could function as indicators of $\mathrm{Cd}$ pollution in water, because they appear to be critical sites of $\mathrm{Cd}$ accumulation. Field studies in aquatic ecosystems generally support experimental findings. $\mathrm{Cd}$ concentrations in the kidney of captured $A$. rostrata and $A$. anguilla (at two reference and contaminated sites) were higher than concentrations in the liver and muscle (Pannetier et al. 2016). 


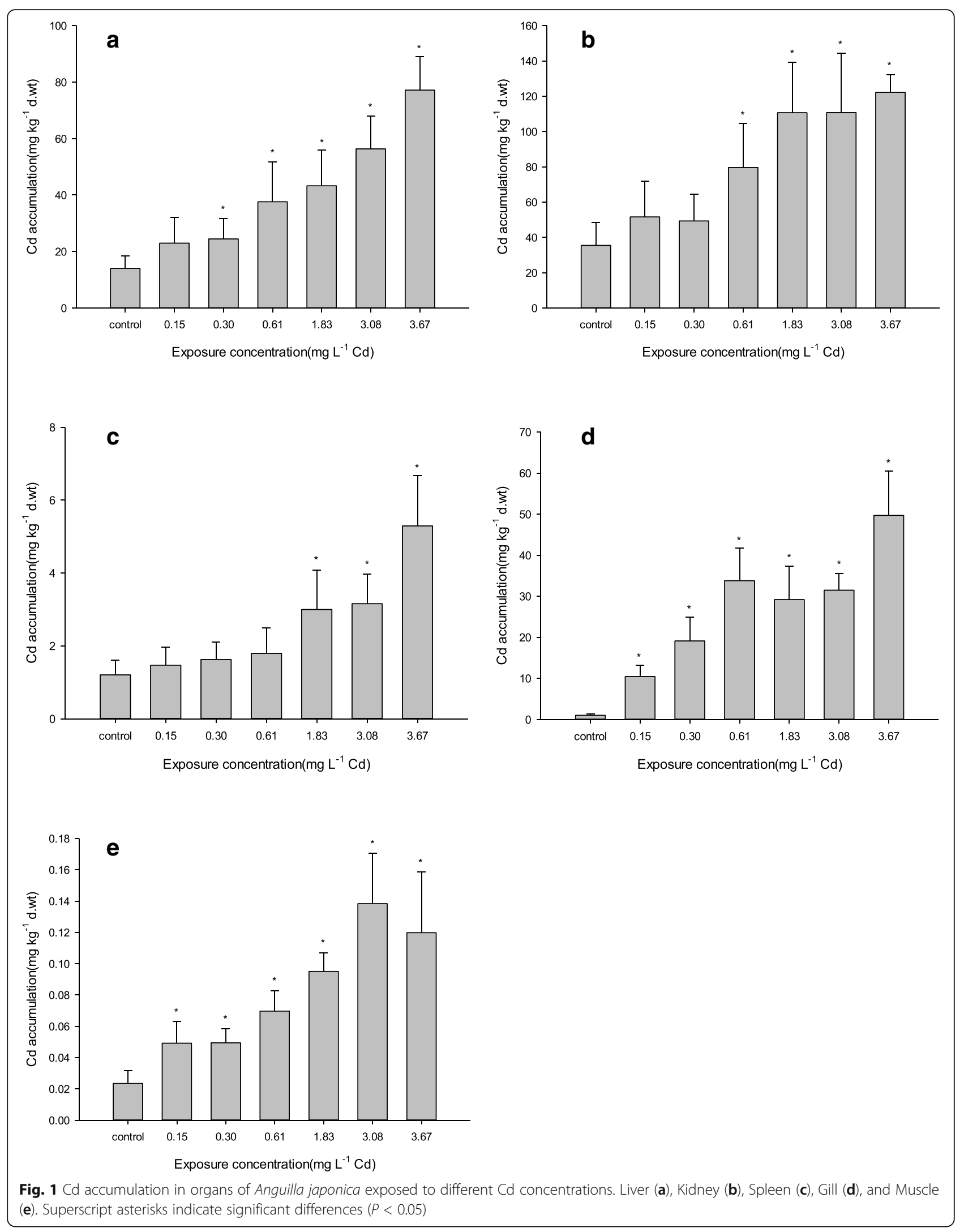



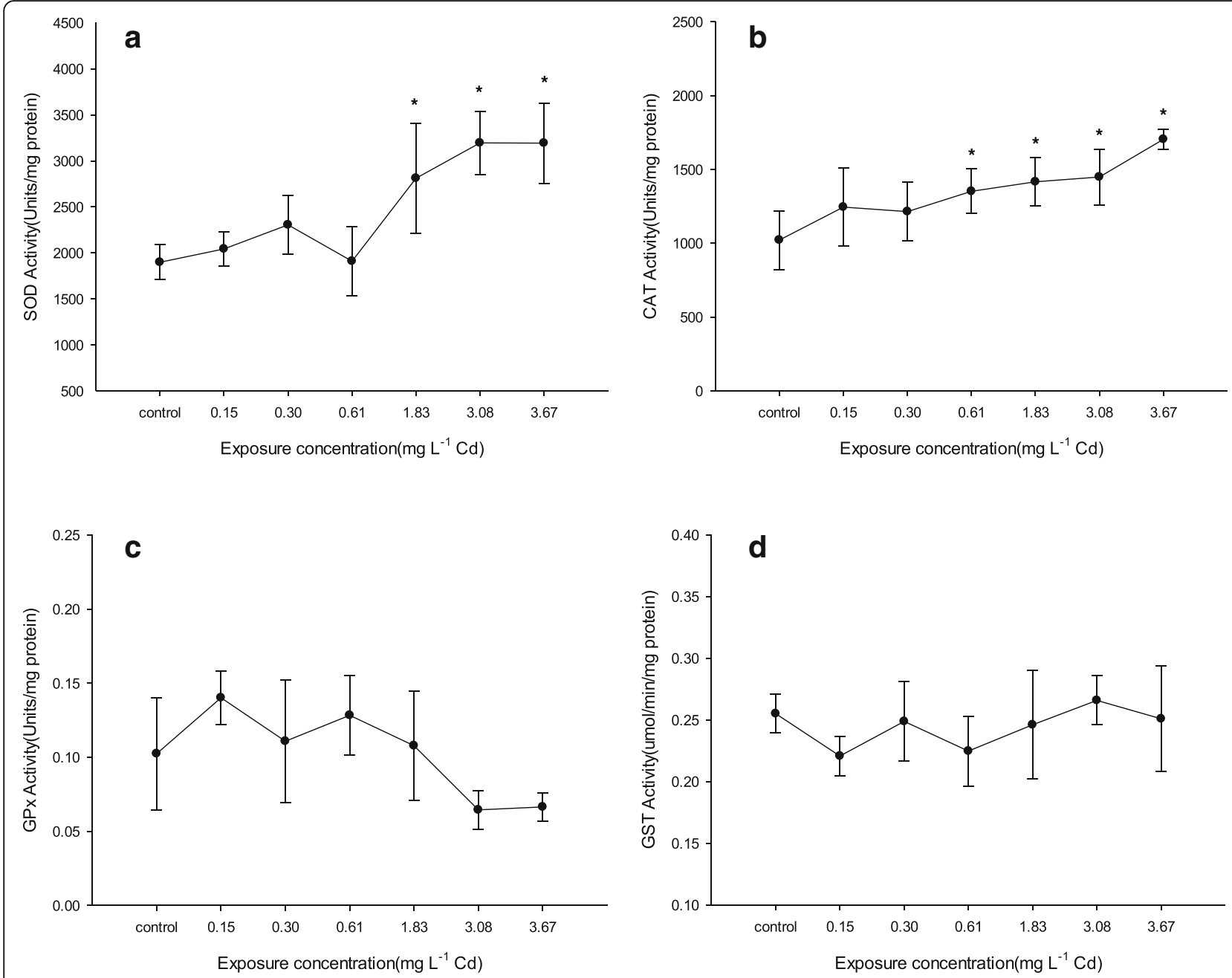

Fig. 2 Activities of antioxidant enzymes in the liver of Anguilla japonica exposed to different Cd concentrations. SOD (a), CAT (b), GPX (c), and GST (d). Superscript asterisks indicate significant differences $(P<0.05)$

Table 4 Comparison of $L C_{50}$ values of $A$. japonica with other freshwater fish studied previously

\begin{tabular}{lllll}
\hline Species & Live stage & Duration $(\mathrm{h})$ & $\mathrm{LC}_{50}\left(\mathrm{mg} \mathrm{L}^{-1}\right)$ & Reference \\
\hline Aguilla japonica & Adult & 96 & 3.61 & This study \\
Anguilla rostrata & & 96 & 0.82 & Rehwoldt et al. (1972) \\
Cyprinus carpio & & 0.24 & Rehwoldt et al. (1972) \\
Oreochromis niloticus & Sac fry & 24 & 1.6 & Andaya and Gotopeng (1982) \\
Oreochromis sp. & Juvenile & 96 & 0.7 & Aldoghachi et al. (2016) \\
Poecilia reticulata & Adult & 96 & 30.4 & Yilmaz et al. (2004) \\
Luciobrama macrocephalus & Juvenile & 96 & 7.42 & Gomes et al. (2009) \\
Channa marulius & Fingerling & 96 & 75.70 & Batool et al. (2014) \\
Wallago attu & Fingerling & 96 & 32.95 & Batool et al. (2014) \\
Rasbora sumatrana & Adult & 96 & 0.10 & Shuhaimi-Othman et al. (2015)
\end{tabular}


We found that $\mathrm{Cd}$ accumulation in the gills increased about fivefold from the control level at 3.67 $\mathrm{mg} \mathrm{L}^{-1} \mathrm{Cd}$ exposure, the highest rate of increase observed in the experiment. Similarly, in common carp (Cyprinus carpio) exposed to $5 \mathrm{mg} \mathrm{L}^{-1}$ of a combined metal solution $(\mathrm{Cr}, \mathrm{Ni}, \mathrm{Cd}$, and $\mathrm{Pb})$ for 32 days, the gills exhibited a higher rate of increase in $\mathrm{Cd}$ accumulation compared with the other tested tissues and also contained the highest in amount of $\mathrm{Cd}$ (followed by the liver, kidney, and flesh) (Vinodhini and Narayanan 2008). This high Cd level is likely explained by the fact that gills are a major point of entry for $\mathrm{Cd}$, which passively diffuses through gill $\mathrm{Ca}$ channels (Verbost et al. 1989). Also, these results indicate that gills are the most sensitive organ to $\mathrm{Cd}$ absorption and accumulation in freshwater fish.

Studies are insufficient about accumulation in the spleen by acute exposure of heavy metals. In our study, $\mathrm{Cd}$ accumulation in the spleen showed a significant increase at $\geq 1.83 \mathrm{mg} \mathrm{L}^{-1} \mathrm{Cd}$ exposure as a higher concentration group than other tissues. It means that $\mathrm{Cd}$ depuration in the spleen is higher than other tissues at the exposure to low $\mathrm{Cd}$ concentration. For example, accumulation in the spleen of brook trout exposed to waterborne $0.001 \mathrm{mg} \mathrm{L}^{-1} \mathrm{Cd}$ as sub-lethal concentration during 77 days has not increased compared with control (Sangalang and Freeman 1979). However, when referring to $\mathrm{LC}_{50}$ concentrations for Oreochromis species in Table 4, accumulation in the spleen of Oreochromis niloticus exposed to waterborne $1 \mathrm{mg} \mathrm{L}^{-1} \mathrm{Cd}$ as high concentration during 15 days has increased highly from control (Cicik et al. 2004). Depuration ability of heavy metals in the spleen could be related to metallothionein (MT) expression and positive effect in specific tissues to remove non-essential metals in tissues. Fold change of MT mRNA levels in the spleen of Korean bitterling, Acheilognathus signifier (cyprinidae), exposed to waterborne $0.5 \mu \mathrm{M}$ copper $(\mathrm{Cu})$ during $48 \mathrm{~h}$ was the high increase following liver among 6 tissues (Lee et al. 2011). Also, as results which inject MT for detoxification in grass carp, Ctenopharyngodon idellus, on the 4 days after injection of $20 \mu \mathrm{M} / \mathrm{kg} \mathrm{CdCl}$, the increase of $\mathrm{Cd}$ accumulation in the spleen suppressed highly more than head-kidney (Huang et al. 2019).

Accumulation of heavy metal in the muscle is important, because it is related to the health of a person by eating muscle as food. Cd accumulation in the muscle showed a significant increase at $\geq 0.15 \mathrm{mg} \mathrm{L}^{-1} \mathrm{Cd}$ exposure. In a previous study, Cd accumulation in the muscle of Sparus aurata was higher than control by acute $\mathrm{Cd}$ exposure $\left(0.5 \mathrm{mg} \mathrm{L}^{-1}\right)$ for short period (2, 4, and 24h) (Souid et al. 2013). Because of rapid accumulation in the muscle by acute $\mathrm{Cd}$ exposure, it is necessary to investigate food safety for fishery and a catch of fish surrounding industrial accident of $\mathrm{Cd}$ spill.
Significance of variance homogeneity was $<0.05$ in all tissues except for the kidney about bioaccumulation between the test groups. These results were related to higher dispersion in 3.08 and $3.67 \mathrm{mg} \mathrm{L}^{-1}$ exposure groups than other groups, because low sample number by mortality affected the degree of dispersion statistically. The high dispersion means that ability of accumulation and depuration can differ between individuals, though the species and environment of the experiment are the same. Nevertheless, the kidney may be considered to be a better selection than other tissues as an indicator of bioaccumulation in eels, Anguilla japonica, by $\mathrm{Cd}$ acute exposure, because the significance of variance homogeneity was $>0.05$.

We also demonstrated that the degree of bioaccumulation reflects variation in waterborne $\mathrm{Cd}$ concentrations. For example, all tissues differed significantly in $\mathrm{Cd}$ accumulation (compared with control) at $\geq 1.83 \mathrm{mg} \mathrm{L}^{-1}$, a point that also marked the highest change rate to $\mathrm{Cd}$ concentrations in experimental water. Additionally, $\mathrm{Cd}$ was present in all tissues (except for muscle) at the highest concentrations under $3.67 \mathrm{mg} \mathrm{L}^{-1}$, a point that also marked the highest $\mathrm{Cd}$ decrement in the water.

Some studies have suggested that $\mathrm{Cd}$ transference from the digestive canal to the liver (via the portal system) does not occur if the fish is exposed to heavy metals for only a short term (Handy 1993). In this study, Cd below a certain concentration $\left(\leq 0.30 \mathrm{mg} \mathrm{L}^{-1}\right)$ accumulated primarily in the gills (the main absorption route), likely because such levels are quickly removed by the liver, the most important organ for detoxification in acute exposure (Chowdhury et al. 2005). In contrast, Cd over a certain concentration (between 0.61 and $3.67 \mathrm{mg}$ $\mathrm{L}^{-1}$ ) accumulated significantly more in the kidney and liver. Although the water in high-exposure groups (4.29 and $5.51 \mathrm{mg} \mathrm{L}^{-1}$ ) had lower rates of change and decrement in $\mathrm{Cd}$ concentrations than water from lowexposure groups, this was due to high eel mortality from $\mathrm{Cd}$ toxicity before bioaccumulation could occur. Therefore, $\mathrm{Cd}$ transference in fish exposed to $\mathrm{Cd}$ for a short term can occur depending on $\mathrm{Cd}$ concentrations without mortality.

In this study, activities of SOD and CAT increased generally, similar to a significant increase of $\mathrm{Cd}$ accumulation in the liver. Significant increase in activities of SOD and CAT by Cd exposure is related to an increase of ROS in fish. As the highest activities of antioxidant enzymes (SOD, CAT), the liver is stronger for oxidative stress than other tissues (Atli et al. 2006). According to a report of Safari (2015), stress from heavy metals induces expression of genes encoding SOD and CAT to detoxify ROS (Rastgoo and Alemzadeh 2011). Similar results about SOD and/or CAT reported in various fish species, e.g., sturgeon, murrel, tilapia (Atli and 
Canli 2007; Dabas et al. 2012; Safari 2015). Results of this study mean that some fish in 3.08 and $3.67 \mathrm{mg} \mathrm{L}^{-1}$ $\mathrm{Cd}$ exposure maintained life by sufficiently increasing activities of SOD and CAT to eliminate ROS in the body. But some studies reported about the decrease of SOD and/or CAT activities unlike the results of ours. For example, CAT activity in the liver of Channa marulius and Wallago attu decreased with increasing exposed Cd concentrations, but SOD activity increased (Batool et al. 2014). And, in the liver of Cyprinus carpio, both CAT and SOD activities decreased after Cd exposure during $96 \mathrm{~h}$ (Karaytug et al. 2011). Roméo et al. (2000) reported that the decrease of CAT activity is attributed to the direct binding of $\mathrm{Cd}$ in CAT at $\mathrm{Cd}$ exposure. These differences can come by fish species, metal species, environmental factors in the experiment, etc. In the study of Saglam et al. (2014), SOD and CAT activities in the liver after Cd and $\mathrm{Cu}$ exposure were different depending on water hardness, respectively.

$\mathrm{Cd}$ induce hepatotoxicity by tightly binding to thiol groups of GSH as the first defense line of acute Cd exposure. Decrease of GSH induces oxidative stress in the liver by free radical production and disruption of the cellular GSH system (Dudley and Klaassen 1984; Liu et al. 2009). Saglam et al. (2014) reported that GPx activity can be considered complementary to CAT activity, but its capacity is smaller than CAT activity for decomposition of the peroxides (Sampaio et al. 2008). In the study of Choi et al. (2007), the expression level of GPx mRNA in the liver of goldfish decreased after $\mathrm{Cd}$ exposure by injection and became undetectable after $12 \mathrm{~h}$ exposure. GPx activity in the liver of gilthead sea bream decreased after waterborne $\mathrm{Cd}$ exposure at $0.1 \mathrm{mg} \mathrm{L}^{-1}$ concentration for 4 days (Cirillo et al. 2012). Crupkin and Menone (2013) reported that GST activity in the liver had no significant change in Australoheros facetus exposed to various $\mathrm{Cd}$ concentrations except for a group of lower concentration, but GST activity of other tissues (gill, brain) altered significantly more than the liver. With consideration for these facts and similar studies, we suppose that our results for decrease tendency of GPx activity in high concentrations and changeless of GST activity were affected by an increase of $\mathrm{Cd}$ ion and decrease of GSH in the liver.

Despite mortality over the majority, the activity change of antioxidant enzyme at $3.67 \mathrm{mg} \mathrm{L}^{-1}$ exposure was smaller than $3.08 \mathrm{mg} \mathrm{L}^{-1}$ exposure. In a previous study, the activity change of antioxidant enzyme was small against the change of mortality with $\mathrm{Cd}$ concentration increase by acute exposure (Batool et al. 2014). Also, the graph of antioxidative activity shows bell shape or changeless with $\mathrm{Cd}$ concentration increase, even though mortality does not occur (Atli et al. 2006; Crupkin and Menone 2013; Souid et al. 2013). On the basis of our and other studies, thus, the activity change of antioxidant enzyme is considered to have limits with experiment species, individuals, kinds of enzymes, etc., even if it is exposed to heavy metal of high concentration that could cause mortality.

Most studies with ours are different in the experimental condition, such as fish species, size, and temperature. They are all necessary to establish accurate environmental pollution indicators. The studies on the effect of antioxidant enzyme activity and accumulation by heavy metal exposure are mostly conducted in chronic toxicity test. So, it is important that our study results have a similar pattern to those of the chronic toxicity test. This is because the effects on chronic toxicity can be inferred through acute toxicity test. We expect that our findings are used as a direct data on food availability of polluted fish by heavy metal exposure of high level, as our study was conducted using fish of the size available as food.

\section{Conclusions}

We investigated $\mathrm{Cd}$ acute toxicity and bioaccumulation in adult $A$. japonica after $96 \mathrm{~h}$ of exposure. The $\mathrm{LC}_{50}$ of $\mathrm{Cd}$ after $96 \mathrm{~h}$ was $3.61 \mathrm{mg} \mathrm{L}^{-1} \mathrm{Cd}$. Cd accumulation was acute in all measured tissues (following the order kidney $>$ liver $>$ gill $>$ spleen $>$ muscle) and corresponded to $\mathrm{Cd}$ decrement and change rate in experimental water. $\mathrm{Cd}$ exposure at $\geq 1.83 \mathrm{mg} \mathrm{L}^{-1}$ led to significant increases as compared with control in $\mathrm{Cd}$ accumulation for all tissues, but the accumulation rate was highest in the gills. In activity alteration of antioxidant enzymes as biomarkers for oxidative stress, both SOD and CAT activities increased $\geq 1.83 \mathrm{mg} \mathrm{L}^{-1}$ significantly. GPx activity showed a decrease tendency at 3.08 and $3.67 \mathrm{mg} \mathrm{L}^{-1} \mathrm{Cd}$ exposure, and GST activity was not changed. Our study results emphasize the need for additional studies on $\mathrm{Cd}$ chronic exposure and depuration of $A$. japonica. The results obtained could aid in setting standards for the influence investigation of $\mathrm{Cd}$ contamination in aquatic environments and processing methods (e.g., instant disuse, usage conversion, or long-term acclimation) for Cd-accumulated eel.

\section{Acknowledgements}

Not applicable

\section{Authors' contributions}

TY Ahn carried out the experiment, analyzed the data, and finalized the manuscript. HJ Park and JH Kim analyzed the experimental data and participated in drafting the manuscript. JC Kang participated in the design of the experiment and drafted the manuscript. All authors read and approved the final manuscript.

Funding

Not applicable

Availability of data and materials

The datasets used and/or analyzed during the current study are available from the corresponding author on reasonable request. 


\section{Ethics approval and consent to participate}

Not applicable

\section{Consent for publication}

Not applicable

\section{Competing interests}

The authors declare that they have no competing interests.

\section{Author details}

'Gyeonggi Province Maritime and Fisheries Research Institute, Yangpyeong 12513, South Korea. ${ }^{2}$ Department of Aquatic Life Medicine, Pukyong National University, Busan 48513, South Korea. ${ }^{3}$ National Institute of Fisheries Science, West Sea Fisheries Research Institute, Taean 32132, South Korea.

\section{Received: 15 May 2020 Accepted: 13 July 2020}

\section{Published online: 25 August 2020}

\section{References}

Adriano DC. Trace elements in terrestrial environments. New York: Springer; 2001. p. 867.

Aldoghachi MAJ, Rahman MM, Yusoff I, Sofian-Azirun M. Acute toxicity and bioaccumulation of heavy metals in red tilapia fish. J Anim Plant Sci. 2016;26: 507-13.

Andaya AA, Gotopeng EU. Cadmium toxicity and uptake in Tilapia nilotica. Kalikasan. 1982:11:309-18

Atli G, Alptekin Ö, Tükel S, Canli M. Response of catalase activity to $\mathrm{Ag}^{+}, \mathrm{Cd}^{2+}$, $\mathrm{Cr}^{6+}, \mathrm{Cu} 2+$ and $\mathrm{Zn}^{2+}$ in five tissues of freshwater fish Oreochromis niloticus. Comp Biochem Physiol Part C. 2006;143:218-24. https://doi.org/10.1016/j. cbpc.2006.02.003

Atli G, Canli M. Enzymatic responses to metal exposures in a freshwater fish Oreochromis niloticus. Comp Biochem Physiol Part C. 2007;145:282-7. https:// doi.org/10.1016/j.cbpc.2006.12.012.

Batool M, Abdullah S, Abbas K. Antioxidant enzymes activity during acute toxicity of chromium and cadmium to Channa marulius and Wallago attu. Pak J Agric Sci. 2014;51:1017-23.

Bradford MM. A rapid and sensitive method for the quantitation of microgram quantities of protein utilizing the principle of protein-dye binding. Anal Biochem. 1976:72:248-54. https://doi.org/10.1016/0003-2697(76)90527-3.

Bryan GW. Some aspects of heavy metal tolerance in aquatic organisms. In: Lockwood APM, editor. Effects of Pollutants on Aquatic Organisms. London: Cambridge University Press; 1976. p. 7-35.

Choi CY, An KW, Nelson ER, Habibi HR. Cadmium affects the expression of metallothionein (MT) and glutathione peroxidase (GPX) mRNA in goldfish, Carassius auratus. Comp Biochem Physiol Part C. 2007;145:595-600. https:// doi.org/10.1016/j.cbpc.2007.02.007.

Chowdhury MJ, Baldisserotto B, Wood CM. Tissue-specific cadmium and metallothionein levels in rainbow trout chronically acclimated to waterborne or dietary cadmium. Arch Environ Contam Toxicol. 2005;48:381-90. https:// doi.org/10.1007/s00244-004-0068-2.

Cicik B, Ay Ö, Karayakar F. Effects of lead and cadmium interactions on the metal accumulation in tissue and organs of the Nile tilapia (Oreochromis niloticus). Bull Environ Contam Toxicol. 2004;72:141-8. https://doi.org/10.1007/s00128-003-0252-5.

Cirillo T, Amodio Cocchieri R, Fasano E, Lucisano A, Tafuri S, Ferrante MC, Carpenè $\mathrm{E}$, Andreani $\mathrm{G}$, Isani $\mathrm{G}$. Cadmium accumulation and antioxidant responses in Sparus aurata exposed to waterborne cadmium. Arch Environ Contam Toxicol. 2012;62:118-26. https://doi.org/10.1007/s00244-011-9676-9.

Crupkin AC, Menone ML. Changes in the activities of glutathione-S-transferases, glutathione reductase and catalase after exposure to different concentrations of cadmium in Australoheros facetus (Cichlidae, Pisces). Ecotoxicol Environ Contam. 2013;8:21-5. https://doi.org/10.5132/eec.2013.01.003.

Dabas A, Nagpure NS, Kumar R, Kushwaha B, Kumar P, Lakra WS. Assessment of tissuespecific effect of cadmium on antioxidant defense system and lipid peroxidation in freshwater murrel, Channa punctatus. Fish Physiol Biochem. 2012:38:469-82.

De Smet H, Blust R. Stress responses and changes in protein metabolism in carp Cyprinus carpio during cadmium exposure. Ecotoxicol Environ Saf. 2001;48:255-62.

Dudley RE, Klaassen CD. Changes in hepatic glutathione concentration modify cadmium-induced hepatotoxicity. Toxicol Appl Pharmacol. 1984;72:530-8. https://doi.org/10.1006/eesa.2000.2011.

Farag AM, Stansburgh MA, Hogstrand C, MacConnell E, Bergman HL. The physiological impairment of free-ranging brown trout exposed to metals in the Clark Fork River, Montana. Can J Fish Aquat Sci. 1995;52:2038-50. https:// doi.org/10.1139/f95-795.

Gomes LC, Chippari-Gomes AR, Oss RN, Fernandes LFL, de Almedia Magris R. Acute toxicity of copper and cadmium for piauçu, Leporinus macrocephalus, and curimatã, Prochilodus vimboides. Acta Sci Biol Sci. 2009;31:313-5. https:// doi.org/10.4025/actascibiolsci.v31i3.5069.

Hammond PB, Foulkes EC. Metal ion toxicity in man and animals. In: Sigel H, editor. Metal lons in Biological Systems. New York: Marcel Deeker Inc.; 1986. p. 157-200.

Handy RD. The assessment of episodic metal pollution. I. Use and limitation of tissue contaminant analysis in rainbow trout (Oncorhynchus mykiss) after short waterborne exposure to cadmium or copper. Arch Environ Contam Toxicol. 1992;22:74-81. https://doi.org/10.1007/BF00213304.

Handy RD. The effect of acute exposure to dietary Cd and Cu on organ toxicant concentrations in rainbow trout, Oncorhynchus mykiss. Aquat Toxicol. 1993; 27:1-14. https://doi.org/10.1016/0166-445X(93)90043-Z.

Haux C, Larsson A. Long-term sublethal physiological effects on rainbow trout, Salmo gairdneri, during exposure to cadmium and after subsequent recovery. Aquat Toxicol. 1984;5:129-42. https://doi.org/10.1016/0166-445X(84)90004-3.

Huang X, Feng Y, Fan W, Duan J, Duan Y, Xiong G, Wang K, Deng Y, Geng Y, Ouyang $P$, Chen D, Yang S. Potential ability for metallothionein and vitamin E protection against cadmium immunotoxicity in head kidney and spleen of grass carp (Ctenopharyngodon idellus). Ecotoxicol Environ Saf. 2019;170:24652. https://doi.org/10.1016/j.ecoenv.2018.11.134.

Javed M. Relationships among water, sediments and plankton for the uptake and accumulation of metals in the river Ravi. Indus J Plant Sci. 2003:2:326-31.

Karaytug S, Sevgiler Y, Karayakar F. Comparison of the protective effects of antioxidant compounds in the liver and kidney of $\mathrm{Cd}$ - and $\mathrm{Cr}$-exposed common carp. Environ Toxicol. 2011;29:129-37. https://doi.org/10.1002/tox. 20779.

Larsson Å, Bengtsson BE, Haux C. Disturbed ion balance in flounder, Platichthys flesus L., exposed to sublethal levels of cadmium. Aquat Toxicol. 1981;1:1935. https://doi.org/10.1016/0166-445X(81)90004-7.

Lee SY, Bang IC, Nam YK. Molecular characterization of metallothionein gene of the Korean bitterling Acheilognathus signifier (cyprinidae). Kor J Ichthyol. 2011; 23:10-20.

Liu J, Qu W, Kadiiska MB. Role of oxidative stress in cadmium toxicity and carcinogenesis. Toxicol Appl Pharmacol. 2009;238:209-14. https://doi.org/10. 1016/j.taap.2009.01.029

Livingstone DR. Oxidative stress in aquatic organisms in relation to pollution and aquaculture. Revue Méd Vét. 2003;154:427-30.

Mason CF. Biology of freshwater fishes. New York: Longman Scientific and Technical Publications; 1991. p. 315.

Okorie OE, Bae JY, Lee JH, Lee SH, Park GH, Mohseni M, Bai SC. Effects of different dietary cadmium levels on growth and tissue cadmium content in juvenile parrotfish, Oplegnathus fasciatus. Asian-Australas J Anim Sci. 2014;27:62-8. https://doi.org/10.5713/ajas.2011.11222.

Öz M. Effects of garlic (Allium sativum) supplemented fish diet on sensory, chemical and microbiological properties of rainbow trout during storage at -18 C. LWT. 2018;92:155-60. https://doi.org/10.1016/j.lwt.2018.02.030.

Öz M, Inanan BE, Dikel S. Effect of boric acid in rainbow trout (Oncorhynchus mykiss) growth performance. J Appl Anim Res. 2018;46:990-3. https://doi.org/ 10.1080/09712119.2018.1450258.

Pannetier P, Caron A, Campbell PGC, Pierron F, Baudrimont M, Couture P. A comparison of metal concentrations in the tissues of yellow American eel (Anguilla rostrata) and European eel (Anguilla anguilla). Sci Total Environ. 2016:569-570:1435-45. https://doi.org/10.1016/j.scitotenv.2016.06.232.

Pinot F, Kreps SE, Bachelet M, Hainaut P, Bakonyi M, Polla BS. Cadmium in the environment: sources, mechanisms of biotoxicity, and biomarkers. Rev Environ Health. 2000;15:299-323. https://doi.org/10.1515/REVEH.2000.15.3.299.

Rand GM, Wells PG, McCarty LS. Fundamental of aquatic toxicology: effects, environmental fate and risk assessment. 2nd ed. Florida: Taylor \& Francis; 1995. p. 1083.

Rastgoo L, Alemzadeh A. Biochemical responses of Gouan (Aeluropus littoralis) to heavy metals stress. Aust J Crop Sci. 2011;5:375-83.

Reddy SJ, Reddy DC. Impact of cadmium toxicity on behavioural and haematological biomarkers of freshwater fish, Catla catla. Int J Bioassays. 2013:2*1199-204

Rehwoldt R, Menapace LW, Nerrie B, Alessandrello D. The effect of increased temperature upon the acute toxicity of some heavy metal ions. Bull Environ Contam Toxicol. 1972;8:91-6. https://doi.org/10.1007/BF01684513. 
Roméo M, Bennani M, Gnassia-Barelli M, Lafaurie M, Girard JP. Cadmium and copper display different response towards oxidative stress in the kidney of the sea bass Dicentrarchus labrax. Aquat Toxicol. 2000;48:185-94. https://doi. org/10.1016/S0166-445X(99)00039-9.

Safari R. Toxic effects of cadmium on antioxidant defense systems and lipid peroxidation in Acipenser persicus (Borodin, 1897). Int J Aquat Biol. 2015;3: 425-32. https://doi.org/10.22034/ijab.v3i6.8.

Saglam D, Atli G, Dogan Z, Baysoy E, Gurler C, Eroglu A. Response of the antioxidant system of freshwater fish (Oreochromis niloticus) exposed to metals $(\mathrm{Cd}, \mathrm{Cu})$ in differing hardness. Turk J Fish Aquat Sci. 2014;14:43-52. https://doi.org/10.4194/1303-2712-v14_1_06.

Sampaio FG, Boijink CL, Oba ET, Santos LRB, Kalinin AL, Rantin FT. Antioxidant defenses and biochemical changes in pacu ( Piaractus mesopotamicus) in response to single and combined copper and hypoxia exposure. Comp Biochem Physiol Part C. 2008:147:43-51. https://doi.org/10.1016/..cbpc.2012.07.002.

Sangalang GB, Freeman HC. Tissue uptake of cadmium in brook trout during chronic sublethal exposure. Arch Environ Contam Toxicol. 1979;8:77-84. https://doi.org/10.1007/BF01055142.

Schreck CB, Moyle PB. Methods for fish biology. Maryland: American Fisheries Society Bethesda; 1990. p. 694.

Shuhaimi-Othman M, Yakub N, Ramle NA, Abas A. Comparative toxicity of eight metals on freshwater fish. Toxicol Ind Health. 2015;31:773-82. https://doi.org/ 10.1177/0748233712472519.

Sjöbeck M-L, Haux C, Larsson Å, Lithner G. Biochemical and hematological studies on perch, Perca fluviatilis, from the cadmium contaminated river Emån. Ecotoxicol Environ Saf. 1984;8:303-12. https://doi.org/10.1016/01476513(84)90035-6.

Souid G, Souayed N, Yaktiti F, Maaroufi K. Effect of acute cadmium exposure on metal accumulation and oxidative stress biomarkers of Sparus aurata. Ecotoxicol Environ Saf. 2013;89:1-7. https:/doi.org/10.1016/j.ecoenv.2012.12.015.

Verbost PM, Flik G, Lock RAC, Wendelaar Bonga SE. Cadmium inhibition of $\mathrm{Ca}^{2+}$ uptake in rainbow trout gills. Am J Phys. 1987;253:216-21. https://doi.org/10. 1152/ajpregu.1987.253.2.R216.

Verbost PM, Flik G, Lock RAC, Wendelaar Bonga SE. Cadmium inhibits plasma membrane calcium transport. J Membr Biol. 1988;102:97-104. https:/doi.org/ 10.1007/BF01870448.

Verbost PM, van Roij J, Flik G, Lock RAC, Wendelaar Bonga SE. The movement of cadmium through freshwater trout branchial epithelium and its interference with calcium transport. J Exp Biol. 1989;145:185-97.

Vinodhini R, Narayanan M. Bioaccumulation of heavy metals in organs of fresh water fish Cyprinus carpio (Common carp). Int J Environ Sci Technol. 2008;5: 179-82. https://doi.org/10.1007/BF03326011.

Woo PTK, Sun YM, Wong MK. The effects of short-term acute cadmium exposure on blue tilapia, Oreochromis aureus. Environ Biol Fish. 1993;37:67-74. https:// doi.org/10.1007/BF00000714.

Yang HN, Chen HC. Uptake and elimination of cadmium by Japanese eel, Anguilla japonica, at various temperatures. Bull Environ Contam Toxicol. 1996; 56:670-6. https://doi.org/10.1007/s001289900098.

Yilmaz M, Gül A, Karaköse E. Investigation of acute toxicity and the effect of cadmium chloride $\left(\mathrm{CdCl}_{2} \cdot \mathrm{H}_{2} \mathrm{O}\right)$ metal salt on behavior of the guppy (Poecilia reticulata). Chemosphere. 2004;56:375-80. https://doi.org/10.1016/j. chemosphere.2003.11.067.

\section{Publisher's Note}

Springer Nature remains neutral with regard to jurisdictional claims in published maps and institutional affiliations.

Ready to submit your research? Choose BMC and benefit from:

- fast, convenient online submission

- thorough peer review by experienced researchers in your field

- rapid publication on acceptance

- support for research data, including large and complex data types

- gold Open Access which fosters wider collaboration and increased citations

- maximum visibility for your research: over $100 \mathrm{M}$ website views per year

At BMC, research is always in progress.

Learn more biomedcentral.com/submissions 